\title{
Some hydrographical observations on salt brine pollution in the Kiel Fjord
}

\author{
Joris M. T. M. GIESKES \\ Institut für Meereskunde der Universität Kiel, Kiel
}

\begin{abstract}
KURZFASSUNG: Einige hydrographische Beobachtungen über Salzlaugeverunreinigung in der Kieler Förde. Seit März 1967 wird ein Salzlager in der Nähe von Kiel ausgespült. $100 \mathrm{~m}^{3}$ pro Stunde laufen von dieser 20\% \%igen Salzlösung seither in den Kieler Hafen. Der Einfluß auf die Salzkonzentration des Fördewassers wurde untersucht, insbesondere die Ausbreitung der gemischten Wassermassen, welche durch Mischung der konzentrierten Salzlösung mit dem Wasser der Fördeoberfläche entstanden ist. Außerhalb der 1000-m-Grenze von der Stelle, an der die konzentrierte Salzlösung in den Hafen läuft, war keine Spur dieser gemischten Wassermassen nachweisbar. Die hydrographischen Verhältnisse im inneren Teil der Kieler Förde wurden von Dezember 1966 bis August 1967 eingehend untersucht. Isoplethendiagramme liefern Auskünfte über die Zirkulation der verschiedenen Wassermassen im Kieler Hafen. In den oberen 15 Metern wurde eine intensive Zirkulation nachgewiesen. Nur drei Löcher im Bodenprofil des Hafens sind von der allgemeinen Zirkulation ausgeschlossen. Die Schichtung in diesen Löchern ist unterschiedlich, und von der Lage dieser Löcher abhängig.
\end{abstract}

\section{INTRODUCTION}

In April 1967, work began on the scouring of a 50,000 $\mathrm{m}^{3}$ cavern in an underground salt layer in the neighbourhood of Kiel. The resulting salt brine, with an initial concentration of about $20 \%$, flows with a rate of 100 to $130 \mathrm{~m}^{3}$ per hour into the inner part of the Kiel Fjord. Every hour an amount of about 22.5 tons of salt is added to the waters of the fjord. The total amount to be added to the fjord will be around 100,000 tons of salt. This amounts roughly to a salt content equal to that of $7.5 \times 10^{6} \mathrm{~m}^{3}$ of $14.5 \%$ Baltic sea-water; $14.5 \%$ salinity corresponds to the average salinity of the surface layer in the fjord during the period of investigation. This quantity of water is only a small portion of the total volume of the area under consideration. If total mixing would occur, no great effect could result, even if there were no significant exchange with the water masses in the outer part of the fjord, and with the Kiel Bight waters in general. A possibility, however, was that only partial mixing would occur, and sea-water of high salinity would form a bottom layer. Such a water mass might conceivably fill some deep holes of the inner fjord and cut them off completely from the annual fjord circulation, resulting in possible ill effects on the waters in the Kiel harbour. 
The purpose of this investigation is to study the influence of this salt brine on the hydrographic conditions of the fjord. The pumping started during the period of the formation of the summer thermocline in 1967. The general hydrographic situation is determined, and special emphasis placed on the influence and spreading of the salt brine.

\section{PREVIOUS WORK ON THE FJORD}

KäNDLeR $(1959,1960)$ studied the hydrography of the Kiel Fjord from 1952 to 1957. KäNDLER (1959) provides average isopleths for temperature and salinity for two of his 3 stations. These diagrams give some rough information on the general conditions in the fjord. It becomes clear that a thermocline begins to form during April and May and disappears in November. In the second paper (KäNDLER 1960) hydrographic sections are presented through the fjord for several months (average data) over the period 1952 to 1957 . Furthermore, some special sections representing typical examples of hydrographical conditions during certain weather periods are given. Finally, KäNDLER provides some isopleths for the periods of November 1951 to June 1952 and of November 1952 to June 1953. From the latter it becomes apparent that variations from the average isopleths occur each year. VISWANATHAN (1960) provides some isopleths at two points in the Kiel Fjord, again showing the high variability in the water masses occupying the fjord. OHL (1959) recorded daily variations in the surface salinity in the Kiel Harbour. From this study rapid changes in the hydrographic conditions in the fjord became apparent.

In general, the hydrography of the fjord is closely related to the conditions in the Kiel Bight. These conditions are dependent on the overall atmospheric conditions in the entire area of the Skagerak, Kattegat, and Baltic Sea (Wattenberg 1941, 1949, KäNDLER 1951). Studies on other fjords, connected to the Kiel Bight, have also been published by KÄNDLER (1953, 1956, 1963). KREY (1959) studied the distribution of dissolved inorganic phosphate in the Kiel Fjord over the period of 1952 to 1957.

The previous work carried out in this area shows that the water masses in the fjord are well circulated. If a new water mass moves into the Kiel Bight, this water mass also penetrates the Kiel fjord. Situations like this develop several times during the year, thus renewing the water masses in the fjord.

\section{DESCRIPTION OF THE AREA OF INVESTIGATION}

Figure 1 shows the inner part of the Kiel Fjord, commonly called Kiel Harbour, which has an average depth of $14 \mathrm{~m}$. There are three excavations in this area, due to dredging. Station A has a depth of $23 \mathrm{~m}$, stations $\mathrm{B}$ and $\mathrm{C}$ are $20 \mathrm{~m}$ and $18 \mathrm{~m}$ deep, respectively. Figure 1 also shows the hydrographic stations, which were visited regularly, usually at intervals of one or two weeks. Station I represents the hydrographic station nearest to the source of salt brine pollution, about $100 \mathrm{~m}$ from the location of its discharge. 


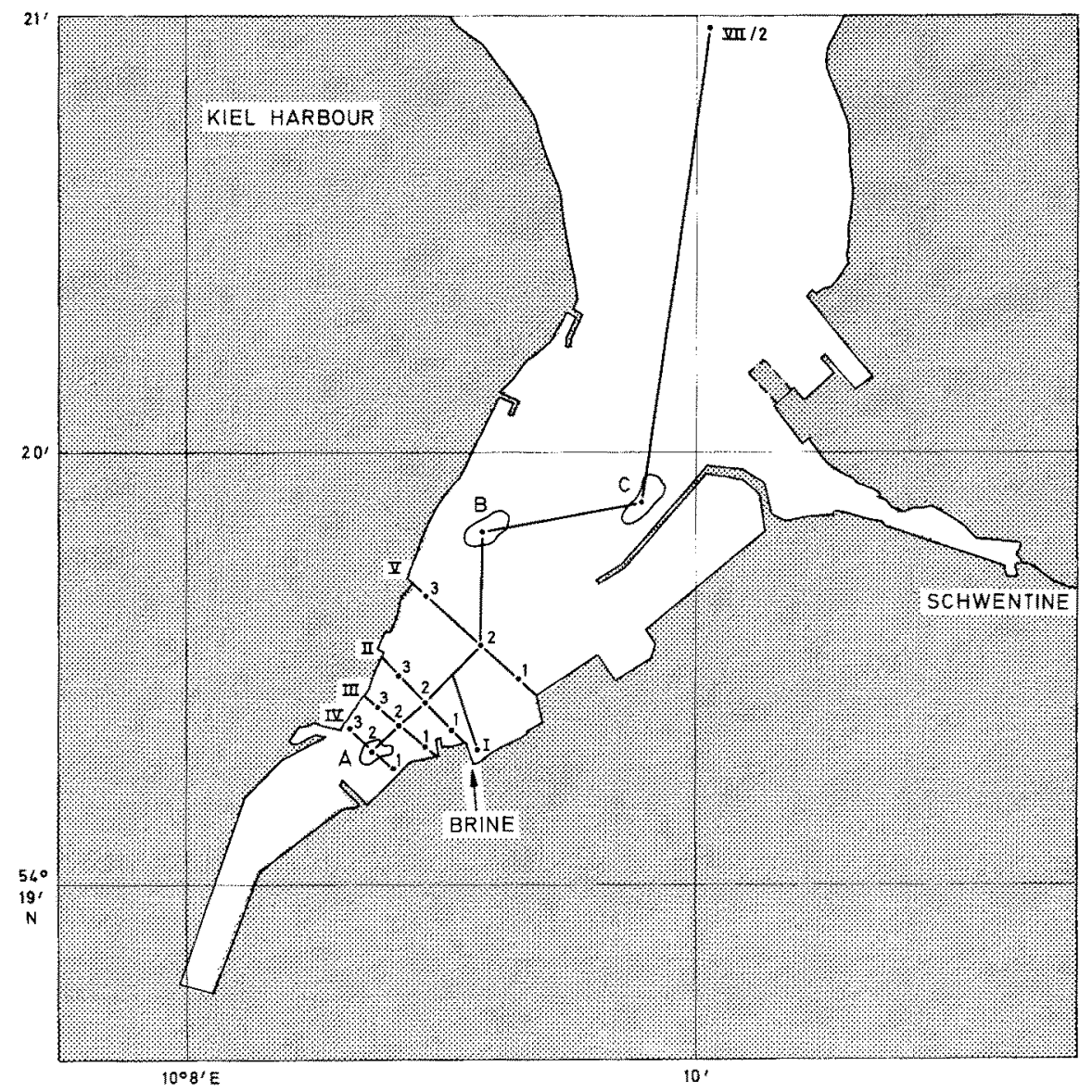

Fig. 1: Kiel Harbour. The dotted lines indicate hydrographic cross-sections

\section{METHOD OF INVESTIGATION}

For the study of the hydrographic conditions of Kiel Harbour, the temperaturesalinity sensor described by Koske (1964) and Greskes (1967) was used. Temperature and salinity were recorded at one meter depth intervals with the sensor in a stationary position. Three water samples were collected at each station for the purpose of calibration. The accuracy of the measurements is estimated to be $\pm 0.1 \% \mathrm{~S}$ and $\pm 0.1 \mathrm{C}$, respectively.

\section{RESULTS AND DISCUSSION}

Figure 2 shows isopleths for temperature, salinity, and density at station A. This station was chosen because it is located in the far corner of the harbour, and, if the 

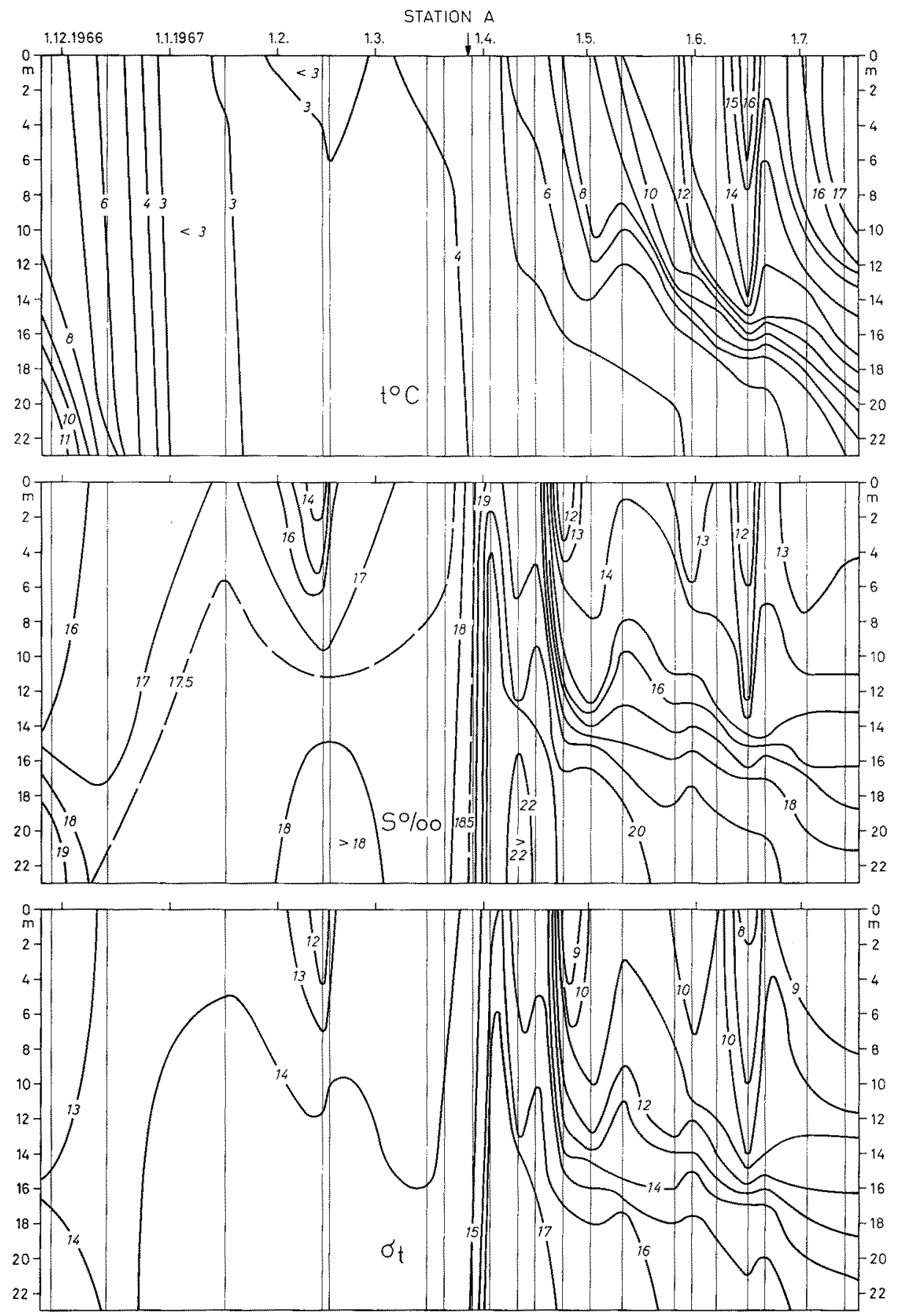

Fig. 2: Isopleths for temperature, salinity, and density at Station $\mathrm{A}$. The arrow indicates the first introduction of brine into the fjord 

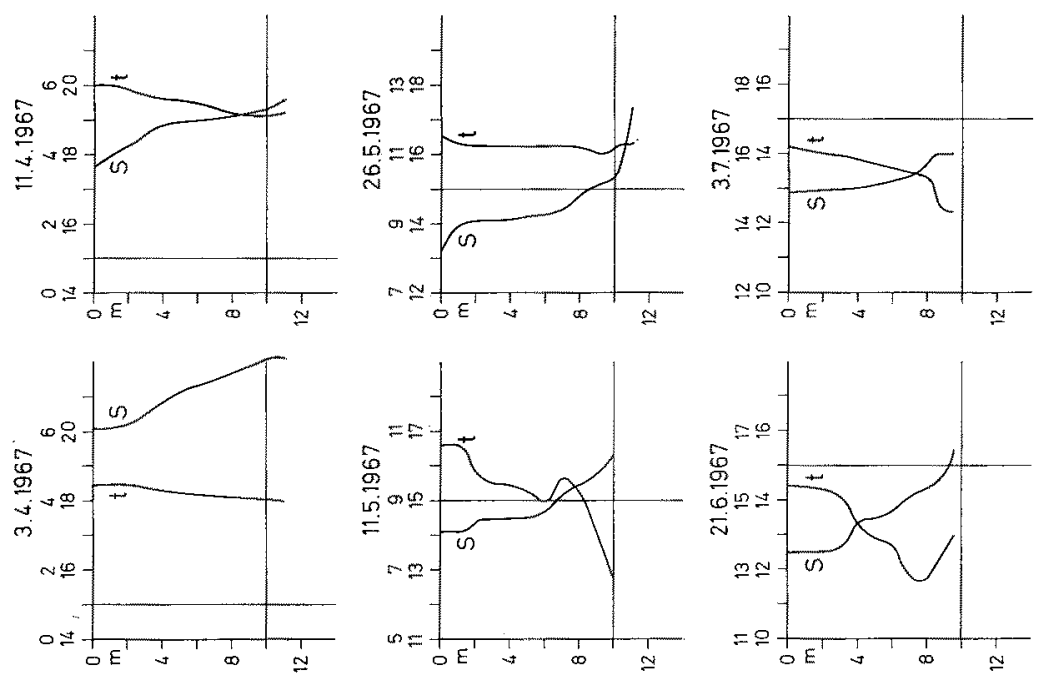

O⿱艹
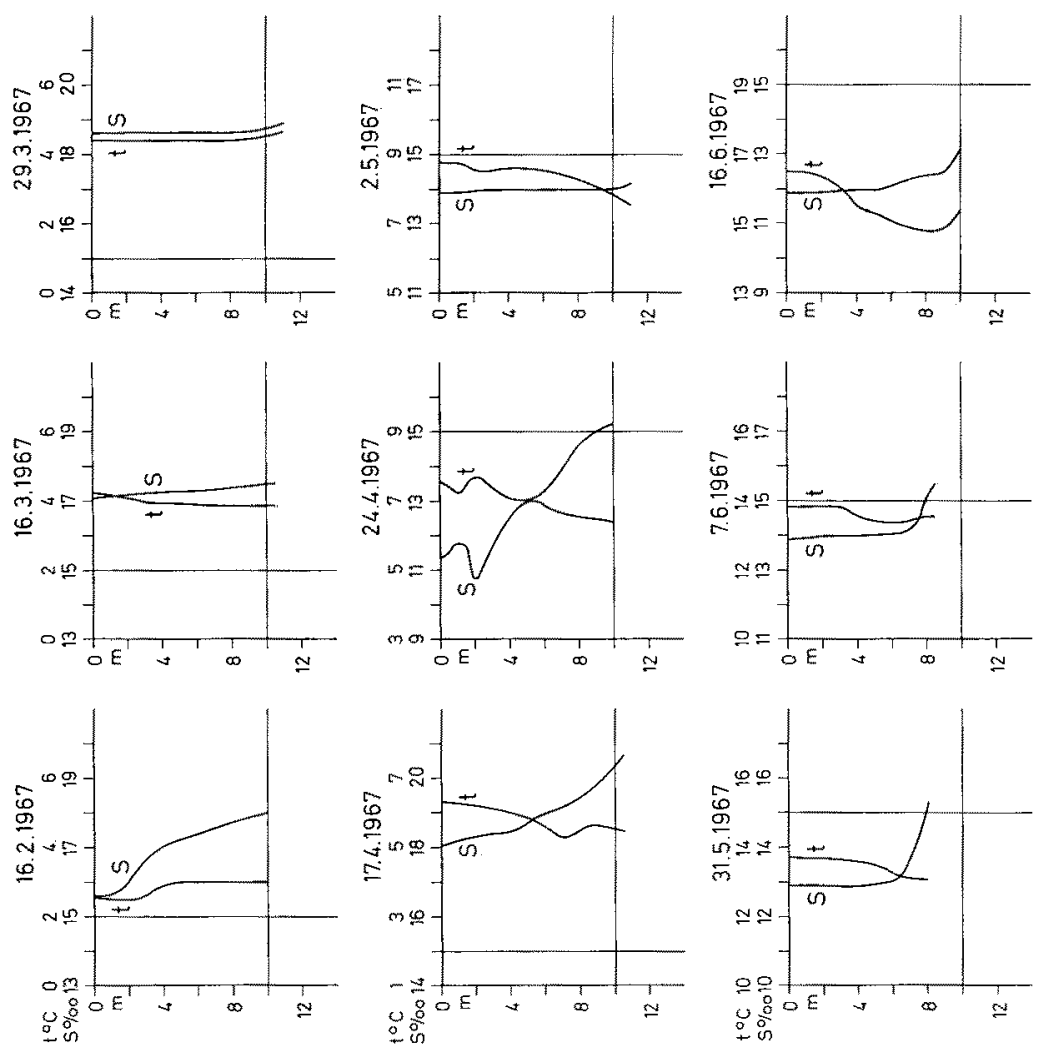
brine would effect the hydrography, this would be most noticable at this station. Moreover, this station is representative in regard to the circulation patterns of the deep holes in the harbour.

In December, a complete turnover occurs in the fjord, after which the water mass cools down rapidly. In February, the surface layer shows lower salinities, presumably due to dilution by Schwentine water; the Schwentine is a small contributory to the fjord. In March, a gradual warming up is evident and towards the end of March a new, highly saline water mass of about $20 \%$ enters the fjord. At the same time the thermocline starts to develop. It is interesting to note that, simultaneously with the replacement of the water mass in the fjord, the brine started to flow into the harbour. After a few weeks the salinity in the surface layers decreased rapidly, indicating the disappearance of the highly saline water mass. For the period of the next two months the deep hole (water from depths below $15 \mathrm{~m}$ ) is cut off from the main circulation of the fjord. The salinity decreases only slowly, presumably due to slow mixing with the supernatant water layers. Also a gradual warming up of this water occurs. The density shows a picture very similar to that of salinity. In June, the entry of another watermass becomes apparent in the surface layers.

The isopleths of Figure 2 show that the water masses in the excavations in the harbour do not participate in the total circulation of the fjord. Furthermore, a continuous renewal in the water masses of the upper layers can be observed, thus showing these water masses to be well circulated. Nevertheless, a certain stratification, even for the layers above $15 \mathrm{~m}$ depth, is always present.

Figure 3 shows the hydrographic situation at station I, which is located about $100 \mathrm{~m}$ from the point of introduction of the salt brine. The brine started to flow on March 28, 1967. The various diagrams show that each time a different situation occurs. On April 17, 1967, the effect of the brine becomes apparent from the temperature curve. During mixing the water assumes the temperature of the surface, but due to its higher salinity, it sinks to a lower level while undergoing additional mixing on its way down. On April 24, 1967, an abnormal, unstable structure was observed. However, not too much significance should be attached to this phenomenon. It might have been caused by the stirring up of a lower water layer by ship propellors. After May 11, 1967 , the presence of a mixed water mass becomes evident. On May 11, the mixed water mass rests on top of the normal thermocline, or halocline. A study of the density distribution shows that the position of the mixed water layer coincides exactly with the density pattern. In most cases increase in salinity due to mixing with the salt brine is estimated to be smaller than $1.5 \%$. Assuming an initial brine concentration of $200 \%$, and a salinity of the surface water of $13 \%$, we can calculate the approximate mixing ratio; it amounts to $1 \mathrm{~m}^{3}$ brine and $130 \mathrm{~m}^{3}$ surface water of $S=13 \%$. Mixing is usually more effective, but even a mixing ratio of $1: 130$ indicates rapid mixing.

In most cases, the mixed water mass can be traced better by using temperature as parameter. With the temperature-salinity sensor at our disposal we were able to follow the spreading of this water mass quite well. An example is the survey of June 7, 1967. Figure 3 shows clearly that a mixed water mass with a mixing ratio of about $1: 125$ is spreading out over the bottom of the fjord at station I. Figure 4 illustrates the section through the area of investigation indicated by the dotted line in Figure 1 representing 

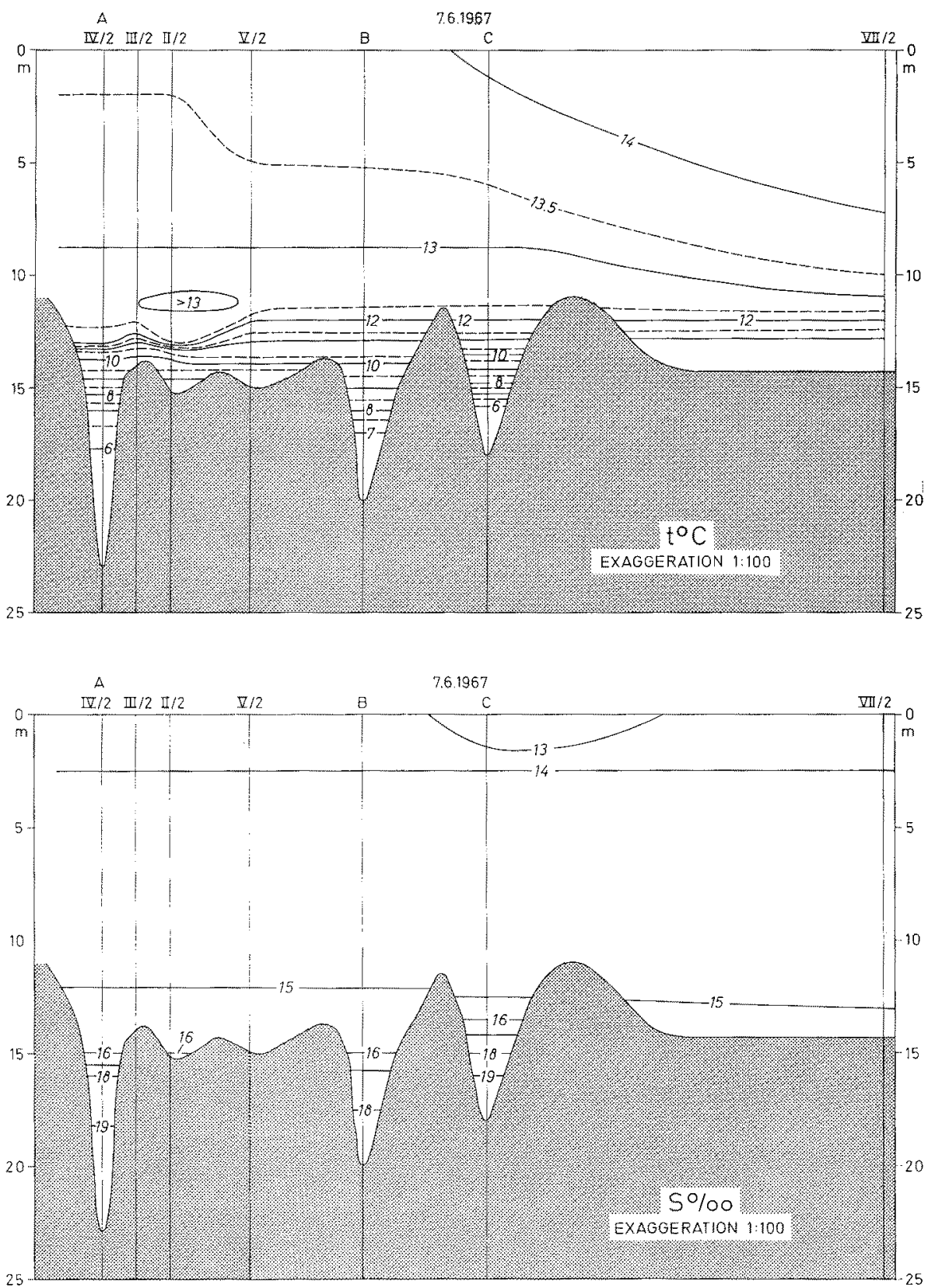

Fig. 4: Cross-section through Kiel Harbour showing temperature and salinity values measured on June 7,1967 

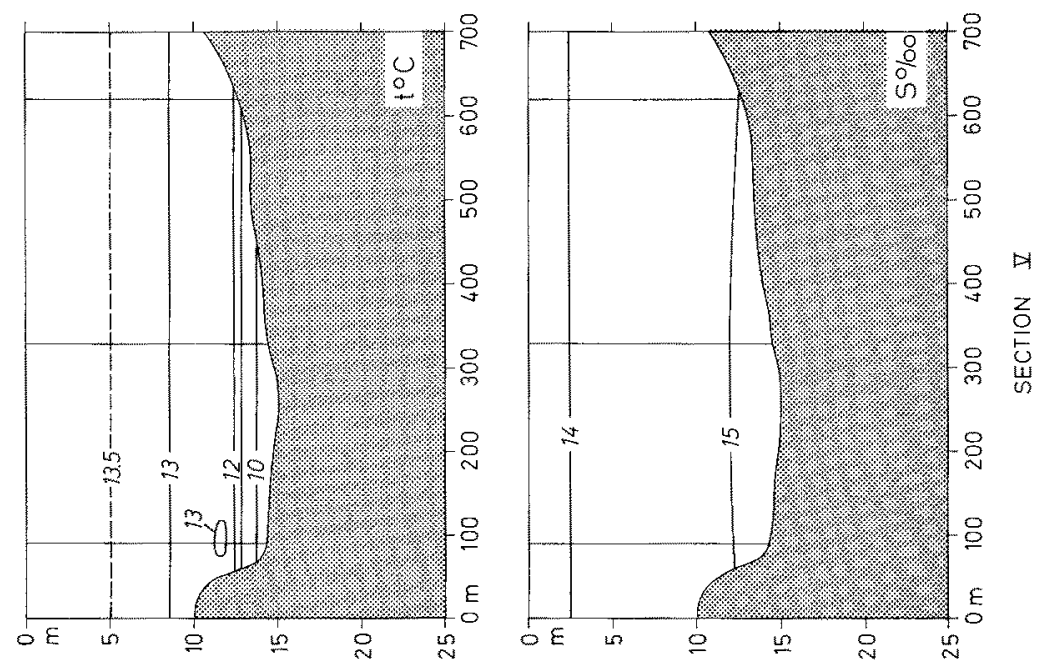

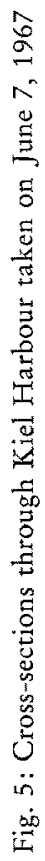
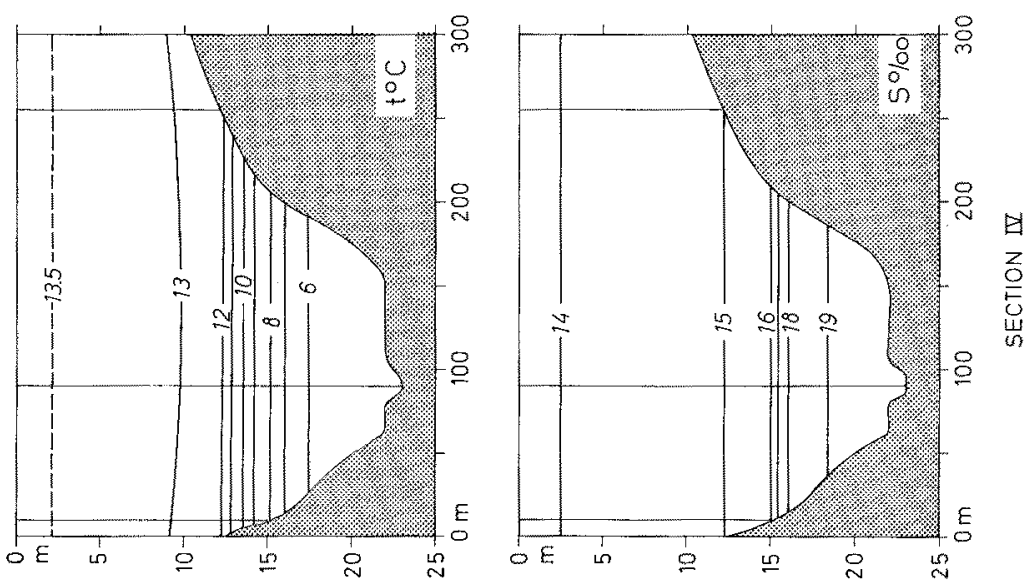
both temperature and salinity as a function of depth and of position. The salinity profile does not show the influence of the mixed water mass, at least not in a definite way. The temperature distribution, however, reveals a region with a small temperature maximum, which can be traced back to the mixed water mass. At station II/2, the isotherms show a definite dent in the curvature, which must be due to the gradual mixing that is taking place. Figure 5 shows the cross sections IV, II and V obtained at the same date. Again, the mixed water mass can only be traced via the temperature profile.

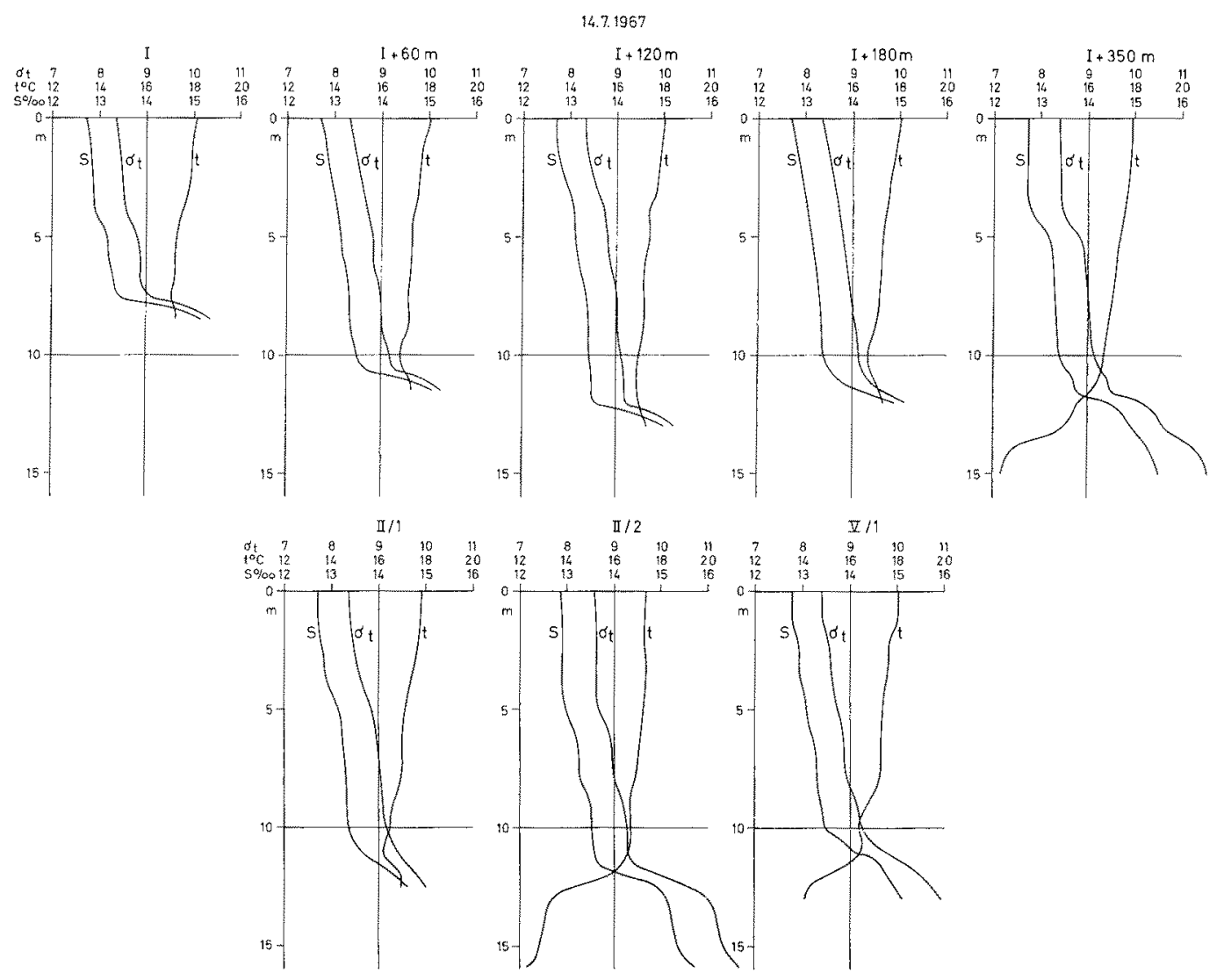

Fig. 6: Vertical distribution of temperature and salinity at Station I; July 14, 1967

Another important feature of Figure 4 is, that the layering in the three excavations (stations A, B, and C) is entirely different in each case. At station A, and especially at station $C$, the degree of exchange with the upper layers is much smaller than at station $B$. Figure 1 shows, that station $B$ is less protected than station $C$ (which is close to the harbour wall), and station $A$ (which is also more sheltered); all three are generally excluded from the water circulation in the fjord. 
On July 14, 1967, an attempt was made to follow the mixed water mass from station I along the dotted line of Figure I. At station I the effect of the brine is clearly present (Fig. 6). At a distance of $60 \mathrm{~m}$ from station I the effect can be observed again, also at distances of 120 and $180 \mathrm{~m}$. For the diagram of station $\mathrm{I}+120 \mathrm{~m}$ a correction of $1 \mathrm{~m}$ in depth seems to be in order. The density distribution seems to agree with this

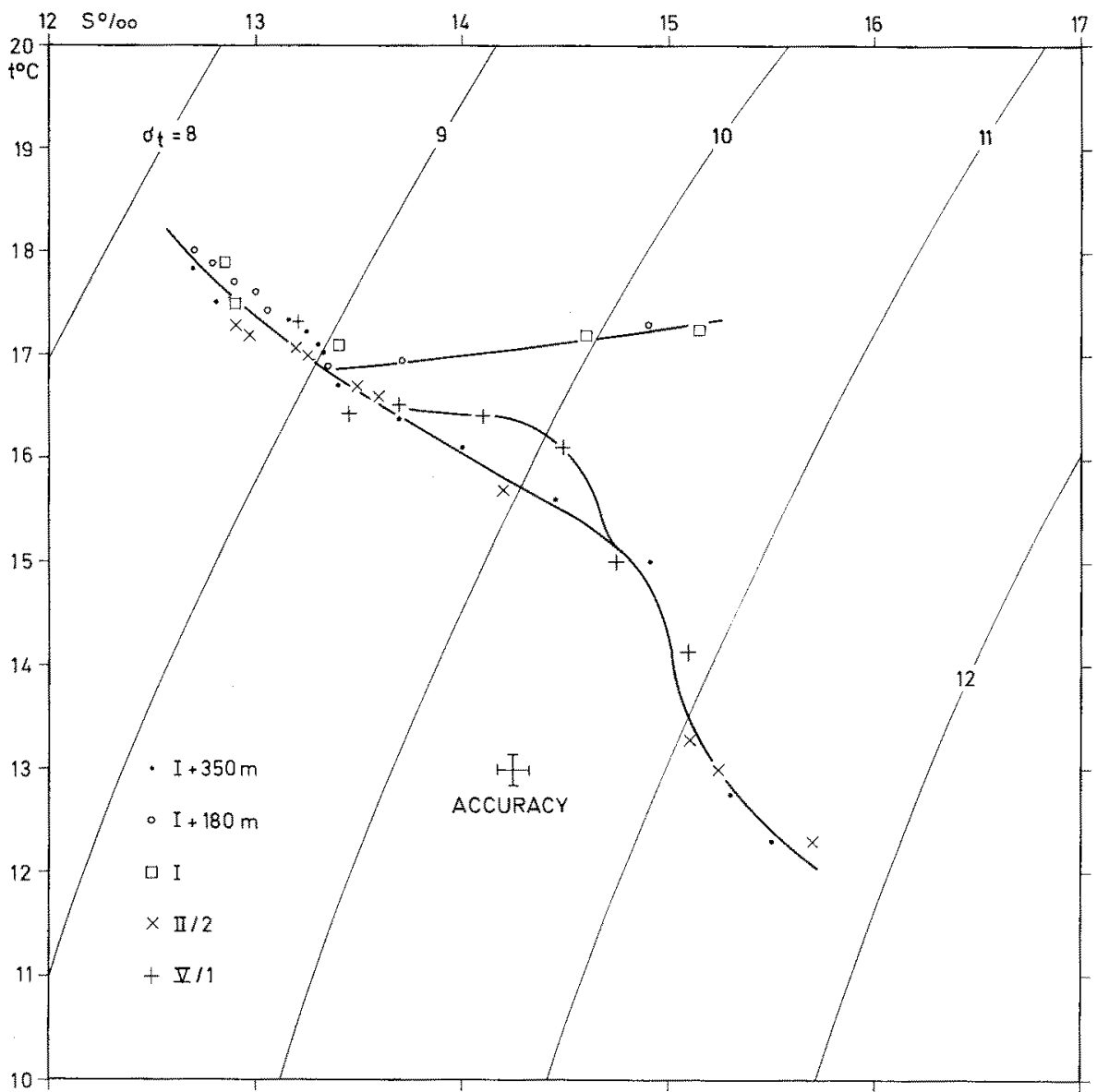

Fig. 7: T,S-diagramm for the stations shown in Figure 6

point of view. An error may have been introduced during the recording with the sensor. At a distance of $350 \mathrm{~m}$ the salt brine effect has disappeared. Station II/1 still shows the presence of the mixed water, but at station II/2 it cannot be traced. Station V/1 shows a slight effect in the temperature curve. This station seems to represent the boundary of the extension of the mixed water mass. Beyond this it disappears due to mixing.

Figure 7 finally represents the T,S-diagram of the measurements which led to Figure 6. From this diagram the mixed water mass can be traced clearly. The diagram 
for station $V / 1$ demonstrates the effect of mixing with the water masses in the fjord. The range of error is indicated in the diagram; it follows that these conclusions seem to be valid.

\section{SUMMARY}

1. A study of the hydrography of the Kiel Fjord has been made from December 1966 to July 1967. On the basis of isopleths, the circulation of the various water masses in the Kiel harbour are discussed.

2. An extensive circulation occurs in the upper $15 \mathrm{~m}$ of the harbour. Only three excavations are effectively excluded from this circulation. The stratification in these excavations differs in each case, and seems to be related to their position in the harbour.

3. The effect of a highly saline brine pumped into Kiel harbour is studied and the extension of the mixed brine layer determined. Its spreading can be traced best with the aid of T,S-diagrams.

4. The results of this survey show that the salt brine mixes rapidly with the water masses of the fjord. The pollution caused by the brine cannot be traced beyond $1000 \mathrm{~m}$ from the location of the initial brine discharge.

\section{LITERATURE CITED}

Gieskes, J. M. T. M., 1967. Continuous measurement of the horizontal and vertical distribution of salinity by means of the membrane salinometer. Verh. K. ned. Akad. Wet. (in press).

KÄNDLER, R., 1951. Der Einfluß der Wetterlage auf die Salzgehaltsschichtung im Übergangsgebiet zwischen Nord- und Ostsee. Dt. hydrogr. Z. 4, 150-160.

- 1953. Hydrographische Untersuchungen zum Abwasserproblem in den Buchten und Förden der Ostküste Schleswig-Holsteins. Kieler Meeresforsch. 9, 176-200.

- 1956. Die hydrologischen Verhältnisse in den Buchten und Förden der Ostküste SchleswigHolsteins im Hinblick auf die Abwasserbelastung. In: Arbeiten des Deutschen FischereiVerbandes, Hamburg. 7, 17-24.

- 1959. Hydrographische Beobachtungen in der Kieler Förde 1952-1957. Kieler Meeresforsch. $15,145-156$.

- 1960. Typen der Salzgehaltsschichtung in der Kieler Förde. Kieler Meeresforsch. 16, 164 $-179$.

- 1963. Hydrographische Untersuchungen über die Abwasserbelastung der Flensburger Förde. Kieler Meeresforsch. 19, 142-157.

Koske, P. H., 1964. Uber ein potentiometrisches Verfahren zur Bestimmung von Chloridkonzentrationen im Meerwasser. Kieler Meeresforsch. 20, 138-142.

KreY, J, 1959. Über den Gehalt an gelösten anorganischen Phosphor in der Kieler Förde 1952-1957. Kieler Meeresforsch. 15, 17-28.

OHL, H., 1959. Temperatur- und Salzgehaltsmessungen an der Oberfläche des Kieler Hafens in den Jahren 1952-1957. Kieler Meeresforsch, 15, 157-160.

Viswanathan, R., 1960. Salzgehalt, Temperatur und Seston in der Kieler Förde 1956 und 1957. Kieler Meeresforsch. 16, 48-56.

Wattenderg, H., 1941. Uber die Grenzen zwischen Nord- und Ostseewasser. Annln Hydrogr. Berl. 69, 265-279.

- 1949. Die Salzgehaltsverteilung in der Kieler Bucht und ihre Abhängigkeit von Strom-und Wetterlage. Kieler Meeresforsch. 6, 17-30. 